\title{
Consumo de TIC y Subjetividades Emergentes: ¿Problemas nuevos?
}

\section{ICT Consumption and Emergent Subjectivities: New Problems?}

\author{
Adriana Gil-Juárez \\ Universitat Autònoma de Barcelona
}

\author{
Montse Vall-llovera \\ Universitat Oberta de Catalunya
}

\author{
Joel Feliu \\ Universitat Autònoma de Barcelona
}

Resumen. En este artículo proponemos una re-lectura e interpretación de los procesos de subjetivación subyacentes a las formas de relación, construcción de identidad y socialización, con el objetivo de desproblematizar las relaciones de las personas con las TIC y entre las personas a través de las TIC. En este sentido, el consumo de TIC no se considera un mero impacto que nos daña o afecta debido a los efectos nocivos de dichas tecnologías, sino como un proceso que no tiene solución de continuidad entre lo "on" y lo "off line"; un proceso de renegociación y resignificación de nuestro entorno socio-técnico y de nuestra subjetividad. Éste implica cambios significativos en las normas y en las maneras de pensar, hacer y sentir. Estos cambios en la forma en que nos relacionamos con los demás y con nosotros mismos son situaciones que tenemos que abordar, y no problemas que tenemos que evitar.

Palabras clave: tecnologías de relación, consumo de TIC, subjetividad, determinismo tecnológico, psicología social crítica.

Abstract. In this article we propose a re-reading and a re-interpretation of subjectivation processes which underlie the forms of relationship, identity construction and socialization. Our main goal is to unproblematize the relationships between people and ICT and between people through ICT. In this respect, we do not consider that consumption of ICT impact us and damages or affects us due to their harmful effects, but as a continuous process between "on" and "off line" situations; a process of renegotiation and redefinition of our sociotechnical environment and our subjectivity. This process involves significant changes in norms, ways of thinking, doing and feeling. These changes in the way of relating to others and to ourselves, are situations for interrogation, not problems to avoid.

Key words: technologies of relationship, ICT comsumption, subjectivity, technologial determinism, critical social psychology.

\section{Introducción}

Según el Estudio General de Medios, a finales del 2008 podíamos encontrarnos en el ciberespacio con 17,9 millones de españoles, el $67 \%$ de los cuales se conectaban a diario. Lo cual suponía, según esta misma publicación, que un $47 \%$ de la población

La correspondencia sobre este artículo debe enviarse a la primera autora a: Departament de Psicologia Social. Facultat de Psicologia. Edifici B. Campus de la Universitat Autònoma de Barcelona. 08193 Bellaterra (Cerdanyola del Vallès). e-mail: adriana.gil@uab.cat. española mayor de 14 años merece la consideración de internauta. Los internautas utilizan redes sociales, hacen compras, y elijen sus viajes y destinos turísticos a través de la red, algunos han conocido a sus parejas en ella, y presentan un denominador común, todos "confiesan" estar "enamorados" de Internet (El País, 2009, p.2). Una buena prueba de ello son los resultados obtenidos en el estudio europeo Mediascope (Asociación Europea de Publicidad Interactiva) llevado a cabo en septiembre del 2008, en que se observó que el internauta español pasa más 
tiempo conectado que frente al televisor, la radio, la prensa y las revistas; gestiona su "estilo de vida" a través de Internet; se comunica a través de redes sociales; y escribe en foros y lugares de comentarios. A ello, hay que añadir que a inicios del 2008, los usuarios de la red no se diferenciaban ni por género -predominando, en algunos momentos, la presencia de mujeres-, ni tampoco por edades, encontrándose prácticamente el mismo número de usuarios en las distintas franjas de edad estudiadas (de entre 15-24, 25-34 y 35-44 años) (Dos a Cero, 2008).

Pensamos que datos como éstos avalan el hecho de que el consumo de tecnologías de la información y la comunicación (TIC) forma parte de nuestra cotidianeidad, y que se encuentran intrínsecamente asociadas a las personas y su entorno relacional. Por ello, en este artículo se propone la reflexión acerca de: si gracias a ellas, o a través de su consumo, aparecen nuevas formas de sociabilidad, y de creación de identidades y nuevos modos de relación. De hecho, y tal como veremos más adelante, se puede hablar de un eje común que atraviesa el consumo de TIC: la comunicación y las relaciones. La mediación de las TIC en el proceso comunicativo ha facilitado y expandido las posibilidades de estar en contacto y relacionarse, al tiempo que, como algunos autores han sugerido, pueden aparecer nuevas (o tal vez no tan nuevas) "problemáticas" asociadas a su uso y consumo. Sin embargo, pensamos que es posible que las "problemáticas advertidas" no sean tales, y puede que se encuentren asociadas no tanto a las derivaciones del uso y consumo de las TIC, sino que más bien puedan explicarse por la aparición de un nuevo paradigma definido por el fluir de las relaciones del plano presencial-personal al plano virtualpersonal (o de lo presencial subjetivo a lo virtual subjetivo), y viceversa, sin solución de continuidad.

Internet y por extensión las TIC, fomentan la "híper comunicación", las posibilidades de relacionarse con los demás desde la "movilidad virtual", el ser y estar en un sitio, pero también, el ser y el estar virtualmente en otros espacios y lugares en y a través de la red. Así pues, parece que el sentido primigenio de uso de las TIC, es el de la relación, evidenciándose que éstas tienen más que ver con lo colectivo que con lo informacional (Gil, 2007); posibilitando la movilidad, en el sentido de encontrarse en distintos espacios, tanto en la red, como telefónicamente a través del móvil, y al mismo tiempo físicamente desde donde uno se encuentra cuando interactúa con la tecnología, favoreciendo asimismo la aparición de nuevos colectivos.

Las TIC han repoblado todos los ámbitos de nuestra vida personal y social, y sus usos y cómo nos apropiamos de ellas trascienden a la mera información. Como indican Blythe, Light y O’Neill (2007), el acceso a las TIC no implica únicamente producción, en el sentido de que éstas se alojan en nuestras diferentes prácticas culturales, sino que involucra también la distribución de dichas prácticas. Es decir, el vehicular la información a través de la comunicación y la relación, mediadas ambas por las diferentes prácticas culturales que realizan las personas gracias a las posibilidades que las TIC les ofrecen (uso de blogs, MP3, MySpace, YouTube, etc.). Las TIC, así entendidas, modulan (en el sentido de grado o gradación) la comunicación, las relaciones, los afectos, las experiencias, las emociones, etc., así como las diferentes formas de consumo y expresión cultural.

Desde este punto de vista, en los siguientes apartados trataremos cuestiones relacionadas con los cambios que se pueden producir en este contexto, como son: la producción simultánea de tecnologías y nuevos contextos sociales; la aparición de nuevas formas de comunicación a raíz de las innovaciones tecnológicas o a la inversa, las nuevas formas de comunicación como posibles generadoras de innovación tecnológica, debido a que los usuarios se apropian de las TIC y hacen un uso de ellas distinto para el que se pensaron en un principio; la aparición de nuevas normas sociales de interacción y la modulación por parte de éstas en los ámbitos de lo público y lo privado; o la aparición de una nueva sociabilidad y formas de conformar identidades y relaciones distintas, como resultado del consumo, usos y apropiaciones, de las TIC.

\section{¿Encantados con la comunicación?}

Hoy no tener conexión es como hace 15 años perderse en un páramo de Los Monegros. Yo veo menos la tele, hablo con más gente que antes, estoy más informado.... (R. R., 44 años, citado en El País, 2009). 
La opinión expresada por R.R. rompe con el supuesto determinismo tecnológico de las TIC, en tanto que éstas irrumpen en nuestras vidas y no podemos hacer nada ante ellas. De hecho, domesticamos las tecnologías, las adaptamos a nuestras necesidades y nos adaptamos a ellas. Se pueden mantener vivas más relaciones, se hacen más duraderas al incrementarse los momentos de conexión ("hablo con más gente que antes" dice R.R.). También, a menudo, se observa una amnesia pretecnológica (Lasén, Finkel y Gordo, 2007), por la que ya no recordamos cómo hacíamos las cosas cuando no disponíamos de las TIC, hasta el punto de compararlo, como en el caso de R.R., con estar perdido en un pedregal. Este "dejar de lado" el pasado sin TIC, y el "ya no concebir" la organización de nuestra vida personal y social sin ellas, conlleva "momentos de de-subjetivación, de negación del yo anterior" (Lasén et al., 2007); y tal y como estos autores señalan: de la aparición de procesos de desubjetivación, emergen nuevas subjetividades, al tiempo que aparecen rápidamente cambios en las normas habituales de etiqueta y comportamientos esperados, con la consecuente redefinición y renegociación de las fronteras entre lo público y lo privado, apareciendo así nuevas normas sociales de interacción "revelando así la fragilidad de las normas existentes relativas a la cortesía, reciprocidad, accesibilidad, expresión de emociones en público" (De Gournay, 2002, en Lasén, 2006). De modo que la subjetividad se actúa cada vez que las TIC median en los procesos comunicativos, dado que es performativa y aparece en interacción con los demás (Gil y Vall-llovera, 2009).

Pero además, se producen también relaciones híbridas entre espacios on/off line. Como indica Gordo refiriéndose al enlace entre lo social y lo tecnológico (2001): “deberíamos pensar sobre los espacios y posibilidades de las relaciones híbridas entre espacios "on-line" y "off-line", así como el modo en que estas relaciones y espacios se reconfiguran mutuamente". Nuestra huella digital posiblemente nos convierte en más "públicos y abiertos" que sin la presencia de la tecnología. De hecho, en ese continuum virtual-presencial, en el que las TIC mediatizan y modulan nuestros actos comunicativos y nuestras relaciones sociales, haciéndonos más móviles (esta- mos, y somos, en distintos espacios y lugares a un tiempo), éstas deben poder ser pensadas como legítimas tecnologías de relación. Ya que el rasgo distintivo de las TIC no es la información que circula por ellas sino las relaciones que posibilitan; las TIC son un espacio de relación que vehicula los procesos de comunicación que -gracias a, o mediante ellas- podemos tener con los otros (Gil, 2007; Gil y Vida, 2007).

En este sentido, grupos sociales que han nacido en la red, como Facebook, Tuenti o Twitter, por poner algunos ejemplos, contribuyen no sólo a la aparición de nuevas formas de comunicación por razón de las innovaciones tecnológicas, sino también a mantenerlas. Así, la red, en tanto que espacio virtual público, seria comparable a una ágora moderna (Gordo y Megías, 2006), donde se producen nuevas formas de subjetivar las relaciones mediadas por la apropiación que se hace de las TIC. Por ejemplo, ha "cuajado" Skype, pero no la videoconferencia, tal vez por la facilidad de uso del primero; o Facebook, que en tanto que espacio colectivo y de redes sociales, facilita el compartir con quien uno elige, expandiendo el marco de las relaciones de amistad; y de paso, refuerza el uso de la fotografía digital, sin ser éste su objetivo principal, dado el uso específico de las TIC que, a menudo, hacen sus usuarios, distinto del que fueron pensadas inicialmente. De modo que, el consumo de tecnología así como las formas en que se usa y cómo se apropian de ella los usuarios, incide en la construcción de la identidad y ofrece nuevas formas de conformarla, mediando en la construcción de los rasgos distintivos de las personas y de los grupos sociales a los que pertenecen.

Los resultados de las investigaciones llevadas a cabo por Pertierra (2005) y Lasén (2006) sobre del consumo de telefonía móvil, aportan evidencias acerca de ello. Dichos autores concluyen que la tecnología es una potente propagadora de las redes personales y sociales, lo cual ha conllevado, entre otros aspectos: la transformación de las formas sociales de interacción; cambios en la forma de gestionar las "fronteras" entre lo personal y lo público; así como cambios en la forma de construcción de la identidad y la gestión de la misma. Aunque Lasén y Pertierra centran sus investigaciones en cómo la telefonía móvil media las subjetividades e identidades socia- 
les, sus hallazgos e interpretaciones de la realidad social acerca de los usos y apropiaciones de los móviles, pueden ser extrapolables al resto de las TIC. Tal y como indica Pablo Rodríguez, director científico de Telefónica I+D: “... a la red de redes se le da un uso para el que no fue concebida, como es su acceso por móvil, [...] el futuro de acceso a Internet es móvil” (El País, 2009, p.6).

Sin embargo, también encontramos discursos en la línea contraria, los cuales analizan desde distintas perspectivas los procesos de fractura de las relaciones sociales tradicionales en base, entre otras, a las transformaciones tecnológicas que pueden haber afectado a "la consistencia de las relaciones sociales y a la vivencia personal del vínculo social, favorecido un proceso de individualización que incide en las sociedades postmodernas presentándose como una amalgama de individuos en flotación que establecen relaciones sociales lábiles y poco duraderas" (Donzelot, Walkowitz, Parker, Varela, Burman y Pastor, 2006).

Creemos que es interesante llegados a este punto, comentar los resultados obtenidos en el estudio llevado a cabo por Lara y sus colaboradores (2009), los cuales realizaron 2000 entrevistas a jóvenes de entre 10 y 18 años, con el fin de conocer la situación real entre los jóvenes y las nuevas tecnologías. Entre los resultados obtenidos, queremos destacar aquellos relacionados con la valoración personal que los jóvenes hacen del uso de Internet, el ordenador, el móvil, el MP3 o similares, y la videoconsola. Para estas tecnologías, la mayoría de los jóvenes consideraron que prescindir de ellas les haría sentir mal, al tiempo que, también para la mayoría eran interesantes y divertidas. En concreto constataron que la tecnología a la que son más adeptos es el teléfono móvil, seguida por el uso de Internet (el $46 \%$ se sentiría mal sin el primero y el $37,3 \%$ sin lo segundo). También, para el $51,8 \%$ y el $45,2 \%$ de los jóvenes, el uso del ordenador y de Internet respectivamente, es interesante y divertido. Además, entre el $24 \%$ y el $30 \%$ valoran a la videoconsola y los MP3 o similares como algo superfluo (aunque no por ello dejan de hacer uso de ambos). Si nos atenemos estrictamente a los datos, podemos pensar, a priori y sin más interpretaciones, en lo que algunos autores han descrito como adicción a las nuevas tecnologías.
Sin embargo, si dichos resultados los releemos atendiendo a todo lo dicho hasta ahora, y desde la consideración de las TIC como tecnologías de relación, los datos evidencian que nos encontramos ante una nueva cultura de comunicación y de relación con los demás, en la que los jóvenes, como nativos digitales que son, lo hacen todo con las nuevas tecnologías. Bajo esta mirada, podremos hablar de apego al objeto (Lasén, 2006), en el sentido de que las TIC "facilitan" la vida, y de que "ciertas cosas no pueden hacerse, $o$ al menos no de la misma manera, sin el artefacto”, y podemos añadir por extensión que, los actos comunicativos y el mantenimiento de las relaciones que estos conllevan, no pueden llevarse a cabo de la misma manera sin las TIC. De modo que, como ya apuntábamos al principio, las TIC mediatizan la comunicación, las relaciones, los afectos, las experiencias, o las emociones; así como las diferentes formas de consumo y expresión cultural. Es por ello que, como mediadora y moduladora, la tecnología reconfigura nuestro modo de pensar y también, porqué no, de sentir; e incide en la formación de nuevas subjetividades y en la reconfiguración de nuestra identidad (en relación con uno mismo y con los demás), en un fluir continuo de lo presencial a lo virtual indiferenciadamente.

\section{¿Problemas nuevos o la unión entre lo virtual y lo personal?}

Los elementos que caracterizan y configuran la identidad son, entre otros, la pertenencia a un grupo, la presencia de un conjunto de atributos, idiosincrasia y los vínculos que se establecen con los otros (Racioppe, Rotouno, Porta, y Poiré, 2008), implicando a su vez el establecimiento de lazos de socialización. Con la aparición de las TIC las formas de relacionarse y socializarse cambian, generándose nuevos modos y redes de socialización y por lo tanto de construcción de identidades.

Nuestro planteamiento a lo largo de este texto, y como ya hemos apuntado anteriormente, propone reflexionar entorno al hecho de que las personas no consumen las TIC pasivamente sino que las integran en sus relaciones con los otros y en su sociabilidad, mediando éstas en el proceso de construcción de identidad. Así pues, el concepto de impacto de la 
tecnología como conjunto de reacciones pasivas de los que la consumen no es asumible. Como alternativa nos acogemos a lo que Feliu ha designado como la metáfora de la lectura:

La "lectura", a diferencia del "impacto", no se "absorbe" sino que se reflexiona, es decir, se contextualiza y se interpreta, en función de lo que uno ha aprendido, de sus experiencias, de sus posiciones ideológicas y estructurales y en contraste con una multitud de otras fuentes de información, incluyendo las "lecturas" que ofrecen otras personas cercanas (Feliu, 2006, p. 108).

Ello implica que consideramos que las personas, cuando consumen TIC, desarrollan de forma activa un proceso de lectura de su entorno -en este caso socio-técnico- buscando significados para interpretar dicho contexto; trasladando el resultado de su lectura a su vida cotidiana, re-escribiéndolo.

Desde esta perspectiva, el consumo de TIC puede verse como un proceso continuo en el que la virtualidad constituye un aspecto más de lo personal, y retomando la metáfora: re-escribimos nuestro entor- no, ahora socio-técnico, cambiando las "reglas del juego" de las relaciones personales, sociales y comunicativas que se desarrollan en un off-on-offon... line continuado. Las implicaciones que ello comporta se reflejan, como hemos visto, en cambios en la significación de las normas y formas de pensar, actuar y sentir, alrededor de nuestra intimidad, relaciones personales y sociales.

Las TIC median a la vez que promueven la reconfiguración continua y constante de los procesos de subjetivación. Dado que hombres y mujeres hemos incorporado y asimilado la tecnología a nuestra vida diaria, nos encontramos ante un cambio de paradigma en cuanto a las formas de relacionarnos, conformar nuestra identidad y socializarnos, procesos ahora mediados por la tecnología. Ello, modifica la interpretación de los procesos de subjetivación e identitarios subyacentes a las mismas, los cuales deben ser re-leídos: las TIC no pueden ser consideradas un problema en sí, sino el paisaje sobre el cual se desarrolla nuestra vida, nuestro medio ambiente.

\section{Extended Summary}

We are proposing a re-reading and interpretation of the subjectivation processes underlying the forms of relating, identity construction and socialization with the aim of unproblemising people's relationships with ICT and between people through ICT.

It is a fact that the consumption of information and communication technologies (ICT) is a part of our everyday life, being intrinsically associated with people and their relational environment. This is why we consider whether, thanks to ICT, or through its consumption, new forms of sociability and of creation of identities and new ways of relating are emerging. We can, in fact, speak of a common axis that crosses the consumption of ICT: communication and relationships. The mediation of ICT in the communicative process has facilitated and expanded the possibilities of being in contact and relating, while at the same time, as some authors state, new (or perhaps not so new) "problems" associated with their use and consumption may appear. However, it is possible that the "problems noticed" are not such and are associated not so much with the derivations of the use and consumption of ICT, but can be explained by the appearance of a new paradigm defined by the flow of relationships from the faceto-face/personal plane to the virtual/personal plane (or face-to-face/subjective to virtual/subjective), and vice versa, without a continuity solution.

Internet and ICT foster "hyper-communication", the possibilities of relating with others through "virtual mobility", being in one place yet also virtually in other spaces and places in and through the net. It appears, then, that the original sense of use of ICT is that of relating, showing that ICT has more to do with the group than with the informational (Gil, 2007); enabling mobility by being in different spaces, both on the net and telephonically by mobile, and at the same time physically wherever a person is when they interact with the technology, similarly favoring the appearance of new groups.

ICT has repopulated every sphere of our personal and social life, and its uses and how we appropriate it transcend mere information. Access to ICT does not solely entail production, with its being housed in our different cultural practices, but also involves the distribution of these practices (Blythe, Light and 
O’Neill, 2007). Channelling the information through communication and relationships, both mediated by the different cultural practices carried out by people thanks to the possibilities that ICT offers. ICT understood as such modulates (in the sense of grade or gradation) communication, relationships, feelings, experiences, emotions, etc., as well as the different forms of consumption and cultural expression.

From this point of view, we are dealing with issues related to the changes that may arise in this context, such as the simultaneous production of technologies and new social contexts; the appearance of new forms of communication based on technological innovations or, the other way round, the new forms of communication as possible generators of technological innovation owing to users appropriating ICT to make a different use of it than was originally designed; the appearance of new social standards of interaction and their modulation in the public and private spheres; or the appearance of a new sociability and ways of shaping identities and different relationships as a result of the consumption, uses and appropriations of ICT.

We domesticate technologies, we adapt them to our needs and we adapt to them. This way, we break with the supposed technological determinism of ICT. It does not break into our lives without our being able to do nothing about it. A pre-technology amnesia is often observed (Lasén, Finkel and Gordo, 2007), where we no longer remember how we did things without ICT. This "leaving aside" the past without ICT, and the "no longer conceiving" the organisation of our personal and social life without it, entails "moments of desubjectivation, of negation of the past me" (Lasén et al., 2007); and as these authors point out: new subjectivities emerge out of the appearance of desubjectivation processes, with changes rapidly appearing in the usual standards of etiquette and expected behaviours, redefining and renegotiating the borders between the public and the private, with the consequent appearance of new social standards of interaction "so revealing the fragility of the existing standards relating to politeness, reciprocity, accessibility, expression of emotions in public" (De Gournay, 2002, in Lasén, 2006). So, subjectivity acts every time ICT mediates in communicative processes, is performative and appears in interaction with others (Gil and Vallllovera, 2009).

In addition, however, there are also hybrid relationships between on/off line spaces. As Gordo states when referring to the link between the social and the technological (2001): "we should think on the spaces and possibilities of the hybrid relationships between on-line and off-line spaces and the way in which these relationships and spaces are mutually reconfigured". Our digital fingerprint possibly makes us more "public and open" than without the presence of technology. In fact, in this virtual/face-to-face continuum, in which ICT mediates and modulates our communicative acts and our social relationships, making us more mobile (we are simultaneously in different spaces and places), it needs to be designed as a legitimate relationship technology. The distinctive trait of ICT is no longer the information that circulates in it but the relationships that it enables; ICT is a relationship space that channels communication processes that - thanks to or through it - we can have with others (Gil, 2007; Gil and Vida, 2007).

In this sense, the social groups that have been born on the internet contribute not just to the appearance of new forms of communication due to technological innovations but also to maintaining them. Insofar as it is a public virtual space, the internet would be comparable to a modern agora (Gordo and Megías, 2006), where new ways of subjectivating the relationships mediated by the appropriation that we make of ICT occur. In this way the consumption of technology and the ways in which it is used and how we appropriate it impact on the construction of identity and offer new ways of shaping it, mediating in the construction of the distinctive traits of people and the social groups to which they belong.

Studies into mobile telephony consumption (Pertierra, 2005, and Lasén, 2006) provide evidence about this. These conclude that technology is a powerful propagator of personal and social networks, which has led, among other things, to the transformation of social forms of interaction; changes in the way of managing the "borders" between the personal and the public; and changes in the way of constructing and managing identity. Although the results refer to how mobile telephony mediates social sub- 
jectivities and identities, the findings and interpretations of the social reality regarding the uses and appropriations of mobiles can be extrapolated to the rest of ICT. As stated by Rodríguez, the science director of Telefónica R+D: “...in the network of networks a use is given to it for which it was not conceived, namely access to it by mobile, [...] the future of internet access is mobile" (El País, 2009).

However, we also find discourses in an opposing vein which analyse the processes of the fracturing of traditional social relationships through the technological transformations that may have affected "the consistency of social relationships and the personal experience of the social bond, favoring a process of individualization that impacts on post-modern societies, being presented as an amalgam of individuals in flotation who establish unstable and short-lived social relationships" (Donzelot, Walkowitz, Parker, Varela, Burman and Pastor, 2006).

We feel that it is appropriate to comment here on some of the results of the study conducted by Lara and his collaborators (2009). These found that the majority of young people that they interviewed stated that not having ICT would make them feel bad, and that they also regarded ICT as interesting and fun. They noted, in turn, that they were adept especially on the mobile telephone and the use of the internet; and for $51.8 \%$ and $45.2 \%$ of young people, the use of the computer and the internet respectively was interesting and fun. They were also usually video-console and MP3 users. It could, initially and with no other interpretations, be thought that these results point to an addiction by young people to ICT.

However, if we re-read these results from the consideration of ICT as a relationship technology, it becomes evident that we are facing a new culture of communication and relationship with others, in which young people, as the digital natives that they are, do everything with the new technologies. Under this view, we speak of devotion to the object (Lasén, 2006), in the sense that ICT "aids" life and "certain things could not be done, or at least not in the same way, without the artefact", and by extension the communicative acts and the maintenance of relationships that this entails, cannot be carried out in the same way without ICT. In this way, it mediates communication, relationships, feelings, experiences or emotions, as well as the different forms of consumption and cultural expression. It is due to this, as mediator and modulator, that technology reconfigures our way of thinking and also, why not, of feeling, and impacts on the formation of new subjectivities and on the reconfiguration of our identity (in relation to oneself and to others) in a continuous flow of the face-to-face towards the virtual without differentiation.

With the appearance of ICT, the ways of relating and socializing change, generating new modes and networks of socialisation, and therefore of construction of identities.

We propose consideration based on the fact that people do not consume ICT passively but they integrate it into their relationships with others and in their sociability, mediating in the identity construction process. Consequently, the concept of impact of technology as a set of passive reactions of those who consume it is not acceptable. As an alternative, we prefer the metaphor of reading:

"Reading", unlike "impact", is not "absorbed" but is considered, in other words, it is contextualized and interpreted according to what one has learnt, to their experiences, and to their ideological and structural positions and in contrast to a multitude of other sources of information, including the "readings" offered by other close people (Feliu, 2006).

This means that we believe that when people consume ICT, they are actively carrying out a process of reading their environment - social-technical in this case - looking for meanings to interpret this context; transferring the result of their reading to their everyday life, rewriting it.

From this perspective, the consumption of ICT can be seen as a continuous process in which virtuality constitutes another aspect of the personal and, taking up the metaphor again, we rewrite our environment, now socio-technical, changing the "rules of the game" of the personal, social and communi-cative relationships that are carried out in a continuing offon-off-on...line. The implications that this entails are reflected in changes in the meaning of the standards and ways of thinking, acting and feeling about our privacy and personal and social relationships.

ICT both mediates and promotes the continuous and constant reconfiguration of the subjectivation 
processes. Since we have incorporated and assimilated technology into our everyday life, we are facing a change of paradigm in terms of the ways of relating, shaping our identity and socialising, now mediated by technology. This modifies the interpretation of the subjectivation and identity processes underlying them, which have to be re-read: ICT cannot be considered to be a problem in itself but the landscape on which our lives, our environment, is played out.

\section{Referencias}

Asociación Europea de Publicidad Interactiva (2008). Internet desbanca a la televisión como medio más 'consumido' en España. Obtenido el 22 de julio del 2009, de http://eiaa.net/news/eiaa-articles-details. asp?id=188\&amp;lang=5.

Blithe, M., Light, A. y O'Neill, S. (2007). Untitled: emerging cultural forms in the digital age. Human Technology, 3 (1), 4-11. Obtenido el 22 de julio del 2009, de http://www.humantechnology. jyu.fi/articles/volume3/2007/blythe-light-oneill.pdf.

Donzelot, J., Walkowitz, J. R., Parker, I., Varela, J., Burman, E. y Pastor, J. (2006). La fragilización de las relaciones sociales. Madrid: Círculo de Bellas Artes. Accesible en http://www.circulobellasartes. com/ag_ediciones-libros.php?ele=47 \&_pagi_pg $=2$.

Dos a Cero (2008). Los internautas en España: la ola 2008 de EGM. En Asociación para la Investigación de los Medios de Comunicación (AIMC). Obtenido el 22 de julio del 2009, de http://dosacero.com/2008/07/los-internautas-en-espana-1a-ola2008-de-egm/.

El País (2009). La red que nos cambió. El País. Internet. 30 de junio de 2009.

Feliu, J. (2006). Adicción o violencia: dilemas sociales alrededor de las nuevas tecnologías y los jóvenes. En Gil, A. y Vall-llovera, M. (Coords.) (2006). Jóvenes en Cibercafés: la dimensión física del futuro virtual. Barcelona: Editorial UOC.

Gil, A. y Vall-llovera, M. (Coords.) (2006). Jóvenes en Cibercafés: la dimensión física del futuro virtual. Barcelona: Editorial UOC.

Gil, A. (2007). Nuevas tecnologías de relación. En José Romay Martinez (Coord.). Perspectivas y retrospectivas de la psicología social en los albores del siglo XXI. Madrid: Biblioteca Nueva.

Gil, A. y Vida, T. (2007). Los Videojuegos. Barcelona: Editorial UOC.

Gil, A. y Vall-llovera. M. (Coords.) (2009). Género, TIC y Videojuegos. Barcelona: Editorial UOC.

Gordo, A. J. y Megías, I. (2006). Jóvenes y cultura messenger. Tecnología de la información y la comunicación en la sociedad interactiva. Madrid: INJUVE. Obtenido el 13 de agosto del 2007, de: http://www.injuve.mtas.es/injuve/contenidos.item. action?id=90016137.

Gordo, A. (2001). Amores on-line/off-line. Teknosphera, 1. Obtenido el 8 de junio del 2009, de http://teknokultura.uprrp.edu/volumenes_anteriores/Backup/rev_31_01_05/volumenes\%20anteriores/vol1/teknosphera/amores_on_line.htm.

Lara, F., Fuentes, M., de la Fuente, R., Pérez del Río, F., Garrote, G. y Rodríguez, M.V. (2009). Uso y abuso de las TIC en la población escolarizada burgalesa 10-18 años. Relación con otras variables psicosociales. Obtenido el 22 de julio del 2009, de http://www.proyectohombreburgos.es/ pdf/Estudio \%20TIC\%20PH-UBU.pdf.

Lasén, A. (2006). Lo social como movilidad: usos y presencia del teléfono móvil. Política y Sociedad, 43, 153-167.

Lasén, A., Finkel, L. y Gordo, A. (2007). Usos del teléfono móvil y comunicación de pareja: un ejemplo de mediación tecnológica de subjetividades. Ponencia presentada en el IX Congreso Español de Sociología, (FES). Barcelona 13 -15 de septiembre.

Pertierra, R (2005). Mobile phones, identity and discursive intimacy. Human Technology, 1, 23-44. Obtenido el 22 de julio del 2009, de http://www.hu mantechnology.jyu.fi/articles/volume1/2005/pertierra.pdf.

Racioppe, B. V., Rotouno, C., Porta, P. I. y Poiré, M. J. (2008). Jóvenes y tics. Modos de socialización y construcción de identidad (es). Ponencia presentada en el marco del $10^{\circ}$ Congreso REDCOM. "Conectados, Hipersegmentados y Desinformados en la Era de la Globalización". Obtenido el 28 de julio del 2009, de http://www.ucasal.net/novedades/archivos/redcom-ponencia/Ejes23y4/Eje3/ Mesa3-2/Racioppe-Rotouno-Porta-Poire.pdf.

Manuscrito recibido: 01/01/2010

Revisión recibida: 20/01/2010

Manuscrito aceptado: 22/01/2010 